\title{
INVESTIGATION OF HORMONE RECEPTOR EXPRESSIONS IN THE FINS OF ORYZIAS WOWORAE (ACTINOPTERYGII: BELONIFORMES: ADRIANICHTHYIDAE)
}

\author{
Arin NGAMNIYOM ${ }^{1 *}$, Thayat SRIYAPAI ${ }^{1}$, and Peechapack SOMYOONSAP ${ }^{2}$ \\ ${ }^{1}$ Faculty of Environmental Culture and Eco-tourism, Srinakharinwirot University, Bangkok 10110, Thailand \\ ${ }^{2}$ Department of Biology, Faculty of Sciences, Srinakharinwirot University, Bangkok 10110, Thailand
}

\begin{abstract}
Ngamniyom A., Sriyapai T., Somyoonsap P. 2014. Investigation of hormone receptor expressions in the fins of Oryzias woworae (Actinopterygii: Beloniformes: Adrianichthyidae). Acta Ichthyol. Piscat. 44 (3): 221-227.
\end{abstract}

Background. In the genus Oryzias, the morphology of the dorsal and anal fin constitute typical secondary sex characteristics that are controlled by sex steroid hormones through hormone receptors. However, the level expressions of hormone receptors in fish fins of this genus have remained to be clarified. To achieve the aims of this study, we completely examined the patterns of hormone receptor expression in all fin types of adult Oryzias woworae Parenti et Hadiaty, 2010.

Materials and methods. The androgen receptor (AR) $\alpha, \operatorname{AR} \beta$, oestrogen receptor (ER) $\alpha$, and ER $\beta$ expression in the dorsal-, anal-, pectoral-, pelvic-, and caudal fins, including the dorsal and ventral edges of the caudal fins, were determined using semi-quantitative RT-PCR.

Results. Hormone receptor expression levels were significantly different in the dorsal-, anal-, and caudal fins of males, including the dorsal and ventral edges of their caudal fins, and in the pectoral and pelvic fins, and the dorsal and ventral edges of the caudal fins of females. AR $\alpha$ and AR $\beta$ levels in dorsal fins and AR $\beta$ levels in anal and caudal fins were higher in males than in females. ER $\alpha$ levels in pectoral fins were higher in males than in females. Conversely, ER $\beta$ levels in the pectoral and pelvic fins and in the dorsal and ventral edges of caudal fins were higher in females than in males.

Conclusion. These results suggest that AR-and ER-mediated functions may regulate sexual dimorphism, and that characteristics of fin morphology are dependent on androgen and oestrogen regulation in adult Oryzias woworae.

Keywords: androgen receptor, oestrogen receptor, dorsal fin, anal fin, pectoral fin, pelvic fin, caudal fin

\section{INTRODUCTION}

Among the various teleosts species, the fishes of the genus Oryzias are notable for their extensive use as vertebrate model organisms for research in many fields, such as endocrinology, developmental biology, and reproductive biology (Chakraborty et al. 2011, Ismail and Yusof 2011, Zhang et al. 2013). In this genus, the dorsal and anal fins are suggested to be typical secondary sex characteristics. These fins are usually longer in mature males than in females (Parenti 2008). The anal fin of the male plays a role in mating with the female for successful fertilisation (Koseki et al. 2000). Moreover, the dorsal and anal fins have been used as bio-indicators for examination of endocrine disrupting chemicals (Hayashi et al. 2007, Ngamniyom and Panyarachun 2012).

Of the sex steroid hormones, androgens and oestrogens act on target cells via their receptors and mediate several physiological processes in many tissues of teleost fish (Amer et al. 2001, Riley et al. 2002). These hormones play a crucial role in sexual differentiation, development of reproductive organs and maintenance of sexual phenotypes in fish (Pawlowski et al. 2004, Guerrero-Estévez and Moreno-Mendoza 2010, Paul-Prasanth et al. 2013). Androgen receptors (AR) and oestrogen receptors (ER) belong to a large family of nuclear hormone receptors that are ligand-induced transcription factors (Todo et al. 1999, Choi 2007). Two AR isoforms (AR $\alpha$ and $A R \beta$ ) have been described in teleost fishes (Ogino et al. 2009). ER $\alpha, E R \beta$, and ER $\gamma$ have been described as the three isoforms of ERs in fishes (Chang et al. 1999, Sabo-Attwood et al. 2004).

Oryzias woworae Parenti et Hadiaty, 2010 (also known as Daisy's ricefish or Daisy's medaka) is a member of the genus Oryzias; it exhibits an autapomorphic colour pattern on its body and is mainly distributed throughout the native freshwater of Sulawesi, Indonesia (Parenti and Hadiaty 2010). This species is also used as

\footnotetext{
* Correspondence: Dr. Arin Ngamniyom, Srinakharinwirot University, Faculty of Environmental Culture and Eco-tourism, 10110, Bangkok, Thailand, phone: +668-1257-4530, fax: +662-260-1532, e-mail: (AN) arin@swu.ac.th,ngamniyom.a@gmail.com.
} 
a non-mammalian vertebrate experimental model with advantageous characteristics: it is easy to maintain, it is reproductively prolific and its secondary sex characteristics are clear. Therefore, in light of this information, we the expression of sex hormone receptors in the fins of Oryzias woworae. The mRNA expression levels of $\mathrm{AR} \alpha$, $\mathrm{AR} \beta, \mathrm{ER} \alpha$, and ER $\beta$ were examined in the dorsal-, anal-, pectoral-, pelvic-, and caudal fins, including the dorsal and ventral edges of the caudal fins of adult fish using semi-quantitative RT-PCR analysis.

\section{MATERIALS AND METHODS}

Fish. Adult Oryzias woworae were taken from the fish breeding tanks maintained in our laboratory and originated from the in-house cultures at the Department of Biology of the Faculty of Sciences of Srinakharinwirot University. Males and females were kept in separate aquaria with a photoperiodic control (12 h for light and 12 $\mathrm{h}$ for dark cycles), a $\mathrm{pH}$ within 7.0-7.4, dissolved oxygen at $8.0-8.3 \mathrm{mg} \cdot \mathrm{L}^{-1}$, and a temperature of $26 \pm 1^{\circ} \mathrm{C}$ for 1 week. These fish were fed ad libitum with a commercial fish feed (Tetra-KilliMin, Tetra, Tokyo, Japan) 2 times per day. Their sex was determined based on the fin morphology. Mature fish were 24-28 mm in standard length. Our experiment was conducted from September 2012 through October 2013.

Fin preparations. Fish were anesthetised with $50 \mathrm{mg} \cdot \mathrm{L}^{-1}$ of an ethyl-3-aminobenzoate methanesulphonate (MS-222) solution (Sigma, St. Louis, MO, USA) and moved to a Petri dish. The whole dorsal-, anal-, pectoral-, pelvic-, and caudal fins from fish individuals were dissected using a clean scalpel. The dorsal and ventral edges of the caudal fin, marked by orange-red lines, comprised the parts of the fin from the 1st through the 3rd and from the 10th through the 12 th fin rays counted from the dorsal or ventral margins; these fin parts were separated from the caudal fins as shown on Fig. 1. Therefore, the caudal fin tissues consisted of the 4th through the 9 th fin rays. Total RNA extraction from three fins was adequate for RT-PCR. One tube combined three fin tissue samples; thus, ten aimed to fill a gap in the existing knowledge concerning

tubes were collected from thirty individuals for each gender. In this way, ten replicate samples were collected.

In order to confirm sexes of histological sections, fish gonads were fixed by Bouin's fixative solution for $12 \mathrm{~h}$ and were dehydrated through a graded ethanol series and embedded in paraffin. Serial sections with $6-\mu \mathrm{m}$ thickness were provide by using a Leica RM2125 microtome and stained with hematoxylin and eosin. Histological views of gonads were observed under a light microscope.

Semi-quantitative RT-PCR. Total RNA from each sample was extracted using the RNeasy Mini Kit (Qiagen, Hilden, Germany) with DNase I treatment for $30 \mathrm{~min}$ at $37^{\circ} \mathrm{C}$, and $100 \mathrm{ng}$ of RNA from each sample was reversetranscribed with SuperScript III One-Step RT-PCR (Invitrogen, USA). The first strand cDNA solution $(0.5 \mu \mathrm{L})$ was used as a PCR template.

The primer sets for $\mathrm{AR} \alpha, \mathrm{AR} \beta, \mathrm{ER} \alpha, \mathrm{ER} \beta$, and $\beta$-actin are shown in Table 1, together with the lengths of the corresponding PCR products. Primers of AR $\alpha$ and AR $\beta$ were designed on the nucleotide data of Japanese medaka, Oryzias latipes (Temminck et Schlegel, 1846) (accession number AB076399 and AB252679, respectively) from GenBank. The cDNA of the housekeeping gene $\beta$-actin was amplified as a loading control and reference for each RT reaction. The PCR conditions for the amplification of cDNA were: $95^{\circ} \mathrm{C}$ for $30 \mathrm{~s}$ for denaturation, $55^{\circ} \mathrm{C}$ for $45 \mathrm{~s}$ for annealing, and $72^{\circ} \mathrm{C}$ for $1 \mathrm{~min}$ for extension in each cycle, with a final extension at $72^{\circ} \mathrm{C}$ for $10 \mathrm{~min}$. In the RT-PCRs, the linear phases were considered to allow semi-quantitative comparisons of cDNAs for the opti-

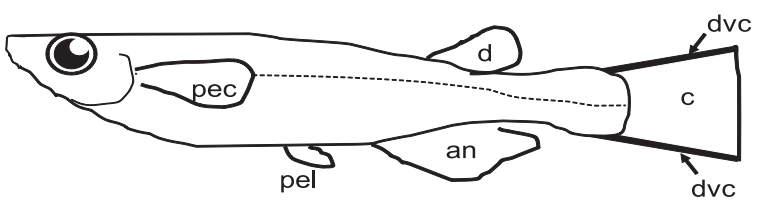

Fig. 1. Diagrammatic illustration of fins of the studied Oryzias woworae; $\mathrm{d}=$ dorsal fin, an = anal fin, $\mathrm{pec}=$ pectoral fin, pel $=$ pelvic fin, $d v c=$ dorsal and ventral edges of caudal fin, $c=$ caudal fin

Table 1

List of primer sequences and product lengths

\begin{tabular}{|c|c|c|c|}
\hline Primer & Sequence & Product (bp) & Reference \\
\hline \multirow[t]{2}{*}{$\mathrm{AR} \alpha$} & 5'-GGATGGGGGTGATGGTGTT-3' & 377 & In this study \\
\hline & 5'-CGACTGGAGGTAGTCCAG-3' & & \\
\hline \multirow[t]{2}{*}{$\mathrm{AR} \beta$} & 5'-GTCAAAGTGGTCAAATGGGC-3' & 227 & In this study \\
\hline & 5'-CTCATCCGTATGCAGTGCTC-3' & & \\
\hline \multirow[t]{2}{*}{$\mathrm{ER} \alpha$} & 5'-ATGATGAAAGGCGGTGTGCGCAAGG-3' & 261 & Hayashi et al. (2007) \\
\hline & 5'-CAACTTCTGACGCGAGCAGAGTATC-3' & & \\
\hline \multirow[t]{2}{*}{$\mathrm{ER} \beta$} & 5'-CTGTTAGATGCCTCGGACCTT-3' & 204 & Inui et al. (2003) \\
\hline & 5'-GATTGGCTGGCTGGTTTCGTG-3' & & \\
\hline \multirow[t]{2}{*}{$\beta$-actin } & 5'-AGGGAGAAGATGACC-3' & 472 & Scholz et al. (2004) \\
\hline & 5'-CGCAGGACGCCATACCAA-3' & & \\
\hline
\end{tabular}


mised reactions according to the methods previously described by Ngamniyom et al. (2009). Thus, the cycle number for the hormone receptors was 30, whereas for $\beta$-actin, the number of cycles was 20 . PCR products were electrophoresed on a $1.5 \%$ agarose gel, stained with ethidium bromide, and viewed under a UV transilluminator. The band intensities of the amplification products were quantified using Scion Image Software for Windows (Scion, MD, USA). To obtain relative expression levels, the intensity of the amplified band for each gene in each sample was divided by the corresponding intensity for $\beta$-actin (Fig. 2).

Statistical analysis. One-way ANOVA followed by Tukey's post-hoc test and the unpaired Student's $t$-test were performed in order to determine significant differ- ences in expression using Statistical Package for the Social Sciences (SPSS) version 20 (SPSS, Chicago IL, USA).

Concerning the animal care, the entire experimental design was approved and permitted by the ethics committee of Srinakharinwirot University's Department of Anatomy in the Faculty of Medicine in accordance with the Guidelines for the Care and Use of Fish in Research, Teaching and Testing (Anonymous 2005).

\section{RESULTS}

Hormone receptor mRNA levels in different fin types. In the dorsal fins, the expression levels of $\operatorname{AR} \alpha, A R \beta$, and $E R \alpha$ were significantly higher than that of ER $\beta$ in males as shown in Fig. 3A. In contrast, no significant difference in hormone receptor expression was found in females. In
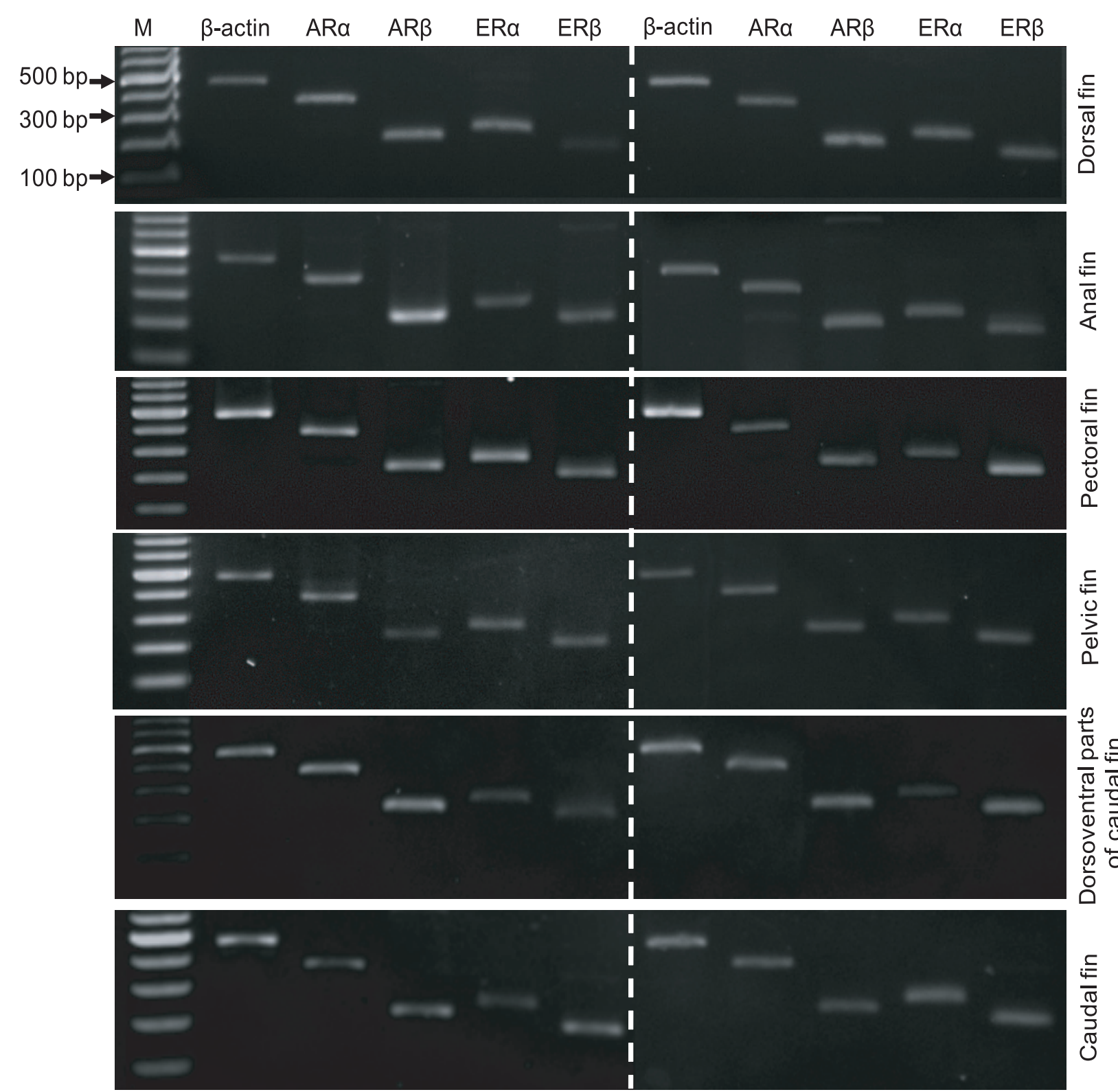

Male

Female

Fig. 2. Gel electrophoresis of the products of semi-quantitative RT-PCR to analyse AR $\alpha, A R \beta, E R \alpha$, and ER $\beta$ expression in the dorsal-, anal-, pectoral-, pelvic-, and caudal fins and in the dorsal and ventral edges of the caudal fins of male and female Oryzias woworae; $\mathrm{M}=$ molecular marker of DNA (100 bp ladder) 
the anal fins, the AR $\beta$ levels were significantly higher than the $A R \alpha, E R \alpha$, and $E R \beta$ levels in males. No significant difference was found among these hormone receptor mRNA levels in females (Fig. 3B). In the pectoral fins, the hormone receptor mRNA levels were not different in males. In contrast, ER $\beta$ levels in females were significantly higher than those of $\operatorname{AR} \alpha, \operatorname{AR} \beta$, and ER $\alpha$ (Fig. 3C). In the pelvic fins, no significant difference was observed among hormone receptors in males. Conversely, in females, ER $\beta$ levels were significantly higher than ER $\alpha$ levels (Fig. 3D). In the dorsal and ventral edges of the caudal fins, AR $\alpha$ and AR $\beta$ levels were highly significantly different from ER $\alpha$ and ER $\beta$ levels in males. ER $\beta$ levels were significantly higher than ER $\alpha$ levels in females (Fig. 3E). In the caudal fins, ER $\beta$ levels were significantly higher than ER $\alpha$ levels in males. However, in females, no significant difference was found for any of the hormone receptor levels (Fig. 3F).

Comparison of hormone receptor mRNA levels in each fin type between males and females. In the dorsal fins, $\operatorname{AR} \alpha$ and $\operatorname{AR} \beta$ expression levels were significantly higher in males than in females. No significant differences in ER $\alpha$ and ER $\beta$ levels were found between males and females (Fig. 3A). In the anal fins, only AR $\alpha$ levels were highly significantly different between males and females (Fig. 3B). In the pectoral fins, ER $\alpha$ levels were significantly higher in males than in females, but ER $\beta$ levels were significantly lower in males than in females. $\mathrm{AR} \alpha$ and $\mathrm{AR} \beta$ levels were not significantly different between males and females (Fig. 3C). In the pelvic fins and dorsal and ventral edges of caudal fins, ER $\beta$ levels were significantly higher in females than in males. No significant differences of $\mathrm{AR} \alpha, \mathrm{AR} \beta$ and $\mathrm{ER} \alpha$ levels were found between both sexes (Figs. 3 D-E). In the caudal fins, ER $\beta$ was more highly expressed than ER $\alpha$ in males. In contrast, no significant difference was found in females between hormone receptor levels. AR $\beta$ levels were significantly higher in males than in females (Fig. 3F).

\section{DISCUSSION}

The AR $\alpha, A R \beta, E R \alpha$, and $\operatorname{ER} \beta$ were expressed in all fin tissues in both sexes. The AR levels were high in the
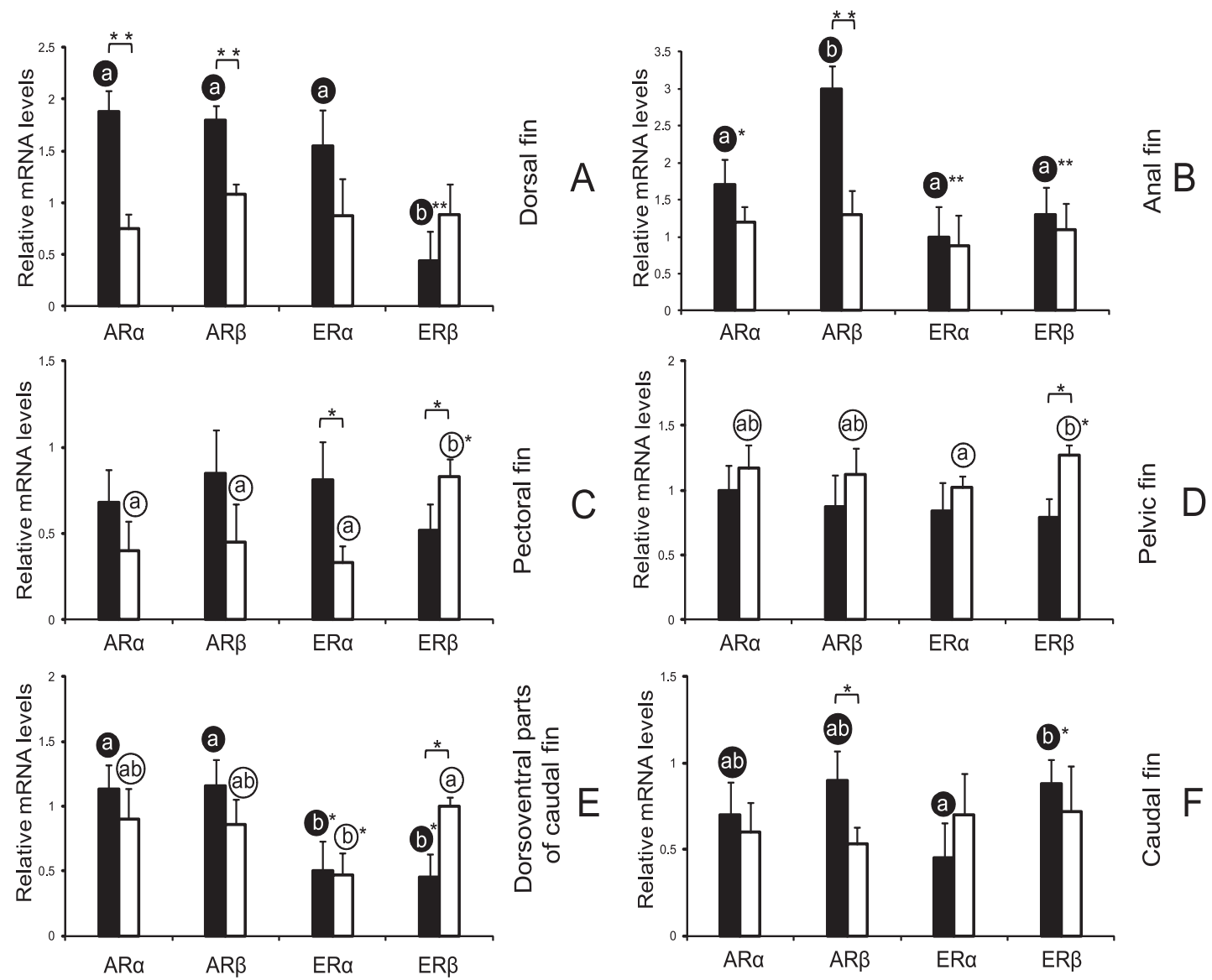

Figs. 3. Expression levels of $\mathrm{AR} \alpha, \mathrm{AR} \beta, \mathrm{ER} \alpha$, and $\mathrm{ER} \beta$ in the dorsal-, anal-, pectoral-, pelvic-, and caudal fins and in the dorsal and ventral edges of the caudal fins of male (black bar) and female (white bar) Oryzias woworae; The expression levels in each fin are relative values compared to the $\beta$-actin mRNA level (mean + standard deviation); Top square brackets indicate significant differences between males and females of each type of fins using the unpaired Student's $t$-test $(*=P<0.05$ and $* *=P<0.01)$; The dissimilar letters in black circle (1) indicate significant differences between fin types of males and in white circle $(i)$ between fin types of females with one-way ANOVA followed by Tukey's post-hoc test $\left(^{*}=P<0.05\right.$ and $\left.* *=P<0.01\right)$ 
dorsal and anal fins in males of Oryzias woworae; this finding was in agreement with a previous report by Ngamniyom et al. (2009) in which AR expression was found to be high in the dorsal and anal fins of male Japanese medaka and Thai medaka, Oryzias minutillus Smith, 1945. With regard to other species, high expression of AR was found in the long gonopodium of the anal fin, a male secondary sex characteristic, in eastern mosquitofish, Gambusia holbrooki Girard, 1859 (see Ogino et al. 2004). From a molecular viewpoint, our finding suggests, that the AR expression levels in the dorsal and anal fins were congruent with their secondary sex characteristics and may involve androgenic control in the male $O$. woworae. In the pectoral and pelvic fins, the ER $\beta$ levels were also higher in females than in males. The ER $\beta$ was predominantly expressed compared with ER $\alpha$ in females. Iwamatsu et al. (2003) reported that the pectoral and pelvic fins exhibited sexual dimorphism in their length in Japanese medaka. However, the pectoral and pelvic fins were rather shorter in males than in females. It has been reported that the administration of oestrogen to Japanese medaka can increase the length of pelvic fins in males and females (Niwa 1959). In Oryzias woworaesimilar to the Japanese medaka - the pairs of pectoral and pelvic fins are larger in females than in males (Parenti and Hadiaty 2010). These results suggest that the oestrogenic effect may regulate the female characteristics, and ER $\beta$ may act as the main ER mediating the growth of pectoral and pelvic fins of $O$. woworae. ER $\alpha$ expression levels in the pectoral fins were dramatically higher in males than in females. This result was incongruent with fin phenotypes, because it is thought that oestrogen might drive feminine hormones controlling the secondary characteristics of females. A well known fact in teleosts fishes is that oestrogens not only play crucial roles in reproductive functions of females but also are important in the reproductive functions of males, including the development of secondary sex characteristics and behaviour (Muramatsu and Inoue 2000, Chakraborty et al. 2011, Cheung et al. 2013). This result suggests that the pectoral fins of males may be the target for oestrogens, even though oestrogens affect that coordinate functions via ER $\alpha$ in these fins have so far been discussed as being related to sex characteristics.

Taking our results into consideration, the $\mathrm{AR} \alpha$ and $\mathrm{AR} \beta$ isoforms differed in their pattern of expression between fins and between sexes. AR $\beta$ expression was dominant and differed in the dorsal and anal fins of males. However, there is insufficient evidence to hypothesise that the dorsal and anal fins of males are specific target tissues for androgen activity in AR $\beta$-mediated regulation, because $\mathrm{AR} \alpha$ and $\mathrm{AR} \beta$ have not been investigated in situ in the fins of teleosts.

The chromatophores in the Japanese medaka are well developed on the male caudal fins and can be regulated by administration of androgenic steroids (Arai and Egami 1961); these chromatophores are reduced in colour by inhibition with oestrogen. In Oryzias woworae, the orange-red pigments are found to be more prominent in males than in females on the upper and lower sides of the caudal fins (Parenti and Hadiaty 2010). In addition, black spots along a caudal fin became more numerous in the male than in the female. In the dorsal and ventral edges of caudal fins, AR $\alpha$ and $\operatorname{AR} \beta$ were highly expressed in male $O$. woworae. ER $\beta$ levels were predominant over ER $\alpha$ levels in females. ER $\beta$ and AR $\beta$ exhibited a sexual dimorphism in expression levels in the dorsal and ventral edges and middle parts of caudal fins, respectively. Androgenic control may create and maintain the brilliant colouration of males on the dorsal and ventral edges of caudal fins. Oestrogens may suppress the pigment colouration through ER $\beta$ in those parts of caudal fins in females. In the caudal fins, the occurrence of the predominant AR $\beta$ in males more so than in females suggests that androgen may regulate pigmentation in males. For both ER isoforms, there was no difference in gene expression levels between the genders, suggesting that oestrogen signalling may be sufficient for feminising the caudal fins.

In our study, the signals of ARs in females were similar to those observed in males, although their relative expression levels were lower in females. In teleosts, androgens are well known to be necessary for oestrogen synthesis through the aromatising of androgens into oestrogens via the aromatase enzyme (Piferrer et al. 1993, Zhang et al. 2012). This suggests that androgen may be required for oestrogen to function in teleost fishes.

In the presently reported study, we characterised the expression patterns of sex steroid hormone receptors across median and paired fin tissues. These patterns correlated with secondary sex characteristics in both sexes of mature Oryzias woworae. It is hypothesised that androgen and oestrogen regulation may confer sex-dependent characteristics of fin morphology, suggesting involvement of AR- and ER-mediated regulation in $O$. woworae. The precise molecular biology in situ, however, has yet to be elucidated in the fins of fish.

\section{REFERENCES}

Amer M.A., Miura T., Miura C., Yamauchi K. 2001. Involvement of sex steroid hormones in the early stages of spermatogenesis in Japanese huchen (Hucho perryi). Biology of Reproduction 65 (4): 1057-1066. DOI: 10.1095/biolreprod65.4.1057

Anonymous 2005. Guidelines on: the care and use of fish in research, teaching and testing. Canadian Council on Animal Care, Ottawa, Canada.

Arai R., Egami N. 1961. Occurrence of leucophores on the caudal fin of the fish (Oryzias latipes) following administration of androgenic steroids. Annotationes Zoologicae Japonenses 34 (4): 185-192.

Chakraborty T., Katsu Y., Zhou L.Y., Miyagawa S., Nagahama Y., Iguchi T. 2011. Estrogen receptors in medaka (Oryzias latipes) and estrogenic environmental contaminants: An in vitro-in vivo correlation. Journal of Steroid Biochemistry and Molecular Biology 123 (3-5): 115-121. DOI: 10.1016/j.jsbmb.2010.11.015

Chang X., Kobayashi T., Todo T., Ikeuchi T., Yoshiura M., Kajiura-Kobayashi H., Morrey C., Nagahama Y. 1999. 
Molecular cloning of estrogen receptors $\alpha$ and $\beta$ in the ovary of a teleost fish, the tilapia (Oreochromis niloticus). Zoological Science 16 (4): 653-658. DOI: 10.2108/ zsj. 16.653

Cheung N.K.M., Cheung A.C.K., Ye R.R., Ge W., Giesy J.P., Au D.W.T. 2013. Expression profile of oestrogen receptors and oestrogen-related receptors is organ specific and sex dependent: the Japanese medaka Oryzias latipes model. Journal of Fish Biology 83 (2): 295-310. DOI: $10.1111 / \mathrm{jfb} .12164$

Choi C.Y. 2007. Effects of $17 \beta$-estradiol on estrogen receptor $\alpha$ and $\beta$ mRNA expression in tissues of the olive flounder (Paralichthys olivaceus). Zoological science 24 (8): 824-828. DOI: $10.2108 / \mathrm{zsj} .24 .824$

Guerrero-Estévez S., Moreno-Mendoza N. 2010. Sexual determination and differentiation in teleost fish. Reviews in Fish Biology and Fisheries 20 (1): 101-121. DOI: 10.1007/s11160-009-9123-4

Hayashi H., Nishimoto A., Oshima N., Iwamuro S. 2007. Expression of the estrogen receptor alpha gene in the anal fin of Japanese medaka, Oryzias latipes, by environmental concentrations of bisphenol A. Journal of Toxicological Sciences 32 (1): 91-96. DOI: 10.2131/jts.32.91

Inui M., Adachi T., Takenaka S., Inui H., Nakazawa M., Ueda M., Watanabe H., Mori C., Iguchi T., Miyatake K. 2003. Effect of UV screens and preservatives on vitellogenin and choriogenin production in male medaka (Oryzias latipes). Toxicology 194 (1-2): 43-50. DOI: 10.1016/S0300-483X(03)00340-8

Ismail A., Yusof S. 2011. Effect of mercury and cadmium on early life stages of Java medaka (Oryzias javanicus): A potential tropical test fish. Marine Pollution Bulletin 63 (5-12): 347-349. DOI: 10.1016/j.marpolbul.2011.02.014

Iwamatsu T., Nakamura H., Ozato K., Wakamatsu Y. 2003. Normal growth of the "see-through" medaka. Zoological Science 20 (5): 607-615. DOI: 10.2108/zsj.20.607

Koseki Y., Takata K., Maekawa K. 2000. The role of the anal fin in fertilization success in male medaka, Oryzias latipes. Fisheries Science 66 (4): 633-635. DOI: 10.1046/j.14442906.2000.00103.x

Muramatsu M., Inoue S. 2000. Estrogen receptors: How do they control reproductive and nonreproductive functions? Biochemical and Biophysical Research Communications 270 (1): 1-10. DOI: 10.1006/bbrc.2000.2214

Ngamniyom A., Magtoon W., Nagahama Y., Sasayama Y. 2009. Expression levels of hormone receptors and bone morphogenic protein in fins of medaka. Zoological Science 26 (1): 74-79. DOI: 10.2108/zsj.26.74

Ngamniyom A., Panyarachun B. 2012. Effects of the herbicide pendimethalin on hormone receptor expressions and dorsal fin biometrics in Thai Medaka, Oryzias minutillus (Actinopterygii: Beloniformes: Adrianichthyidae). Acta Ichthyologica et Piscatoria 42 (3): 239-246. DOI: 10.3750/AIP2011.42.3.08

Niwa H.S. 1959. Inhibitory effect of male hormone on growth and regeneration of the pelvic fin in the medaka, Oryzias latipes. Embryologia 4 (4): 349-358. DOI: 10.1111/j.1440169X.1959.tb00260.x
Ogino Y., Katoh H., Kuraku S., Yamada G. 2009. Evolutionary history and functional characterization of androgen receptor genes in jawed vertebrates. Endocrinology 150 (12): 5415-5427. DOI: 10.1210/ en.2009-0523

Ogino Y., Katoh H., Yamada G. 2004. Androgen dependent development of a modified anal fin, gonopodium, as a model to understand the mechanism of secondary sexual character expression in vertebrates. FEBS Letters 575 (1-3): 119-126. DOI: $10.1016 /$ j.febslet.2004.08.046

Parenti L.R. 2008. A phylogenetic analysis and taxonomic revision of ricefishes, Oryzias and relatives (Beloniformes, Adrianichthyidae). Zoological Journal of the Linnean Society 154 (3): 494-610. DOI: 10.1111/j.1096-3642. 2008.00417.x

Parenti L.R., Hadiaty R.K. 2010. A new, remarkably colorful, small ricefish of the genus Oryzias (Beloniformes, Adrianichthyidae) from Sulawesi, Indonesia. Copeia 2010 (2): 268-273. DOI: 10.1643/CI-09-108

Pawlowski S., Sauer A., Shears J.A, Tyler C.R., Braunbeck T. 2004. Androgenic and estrogenic effects of the synthetic androgen $17 \alpha$-methyltestosterone on sexual development and reproductive performance in the fathead minnow (Pimephales promelas) determined using the gonadal recrudescence assay. Aquatic Toxicology 68 (3): 277-291. DOI: 10.1016/j.aquatox.2004.03.018

Paul-Prasanth B., Bhandari R.K., Kobayashi T., Horiguchi R., Kobayashi Y., Nakamoto M., Shibata Y., Sakai F., Nakamura M., Nagahama Y. 2013. Estrogen oversees the maintenance of the female genetic program in terminally differentiated gonochorists. Scientific Reports 3: 2862. DOI: 10.1038/srep02862

Piferrer F., Baker I.J., Donaldson E.M. 1993. Effects of natural, synthetic, aromatizable, and nonaromatizable androgens in inducing male sex differentiation in genotypic female chinook salmon (Oncorhynchus tshawytscha). General and Comparative Endocrinology 91 (1): 59-65. DOI: 10.1006/gcen.1993.1104

Riley L.G., Hirano T., Grau E.G. 2002. Disparate effects of gonadal steroid hormones on plasma and liver mRNA levels of insulin-like growth factor-I and vitellogenin in the tilapia, Oreochromis mossambicus. Fish Physiology and Biochemistry 26 (3): 223-230. DOI: 10.1023/A: 1026209502696

Sabo-Attwood T., Kroll K.J., Denslow N.D. 2004. Differential expression of largemouth bass (Micropterus salmoides) estrogen receptor isotypes alpha, beta, and gamma by estradiol. Molecular and Cellular Endocrinology 218 (1-2): 107-118. DOI: 10.1016/j.mce.2003.12.007

Scholz S., Kordes C., Hamann J., Gutzeit H.O. 2004. Induction of vitellogenin in vivo and in vitro in the model teleost medaka (Oryzias latipes): Comparison of gene expression and protein levels. Marine Environmental Research 57 (3): 235-244. DOI: 10.1016/S01411136(03)00082-5

Todo T., Ikeuchi T., Kobayashi T., Nagahama Y. 1999. Fish androgen receptor: cDNA cloning, steroid activation of transcription in transfected mammalian cells, and tissue mRNA 
levels. Biochemical and Biophysical Research Zhang J., Huang J.-Q., Li Y.-Y., Wang N., Sun J., Wang T.-Z., Communications 254 (2): 378-383. DOI: 10.1006/bbrc. 1998.9919

Zhang Y., Zhang S., Zhou W., Ye X., Ge W., Cheng C.H.K., Lin H., Zhang W., Zhang L. 2012. Androgen rather than estrogen up-regulates brain-type cytochrome P450 aromatase (cyp19a1b) gene via tissue-specific promoters in the hermaphrodite teleost ricefield eel Monopterus albus. Molecular and Cellular Endocrinology 350 (1): 125-35. DOI: 10.1016/j.mce.2011.12.001

Chen S.-L. 2013. Histological observations of medaka (Oryzias latipes) gonad sexual differentiation and development. Zoological Research 34 (5): 464-470. DOI: 10.11813/j.issn.0254-5853.2013.5.0464 [In Chinese with English abstract.]

Received: 2 January 2014

Accepted: 12 June 2014

Published electronically: 15 October 2014 